\title{
Condition of Green Ash, Incidence of Ash Yellows Phytoplasmas, and Their Association in the Great Plains and Rocky Mountain Regions of North America
}

\author{
J. A. Walla, North Dakota State University, Fargo; W. R. Jacobi, Colorado State University, Fort Collins; N. A. \\ Tisserat, Kansas State University, Manhattan; M. O. Harrell, University of Nebraska, Lincoln; J. J. Ball, South \\ Dakota State University, Brookings; G. B. Neill and D. A. Reynard, PFRA Shelterbelt Centre, Agriculture and \\ Agri-Food Canada, Indian Head, SK, Canada; Y. H. Guo, North Dakota State University, Fargo; and L. Spiegel, \\ Wyoming State Forestry Division, Cheyenne
}

\begin{abstract}
Walla, J. A., Jacobi, W. R., Tisserat, N. A., Harrell, M. O., Ball, J. J., Neill, G. B., Reynard, D. A., Guo, Y. H., and Spiegel, L. 2000. Condition of green ash, incidence of ash yellows phytoplasmas, and their association in the Great Plains and Rocky Mountain regions of North America. Plant Dis. 84:268-274.

About $50 \%$ of 1,057 green ash (Fraxinus pennsylvanica) systematically sampled in the Great Plains and Rocky Mountain regions had substantial dieback (>10\% of crown branches with dieback), and the average growth ring width during the last 20 years was $2.9 \mathrm{~mm}$. The overall condition of the population was rated fair. Ash yellows phytoplasmas were identified at 102 of 106 sites throughout six U.S. states (North Dakota, South Dakota, Wyoming, Nebraska, Colorado, Kansas) and three Canadian provinces (Alberta, Saskatchewan, Manitoba). These phytoplasmas had not previously been known in Alberta, Saskatchewan, Manitoba, Wyoming, Colorado, or Kansas. Incidence of phytoplasmal detection ranged from 16\% in Wyoming to $71 \%$ in South Dakota. Incidence varied in the range 41 to $67 \%$ across site types and crown dieback classes. Incidence was highest in rural plantings, in trees with the most crown dieback, and in larger diameter trees. No significant relationships were detected between presence of ash yellows phytoplasmas and radial growth rates of trees.
\end{abstract}

Additional keyword: windbreaks

Green ash (Fraxinus pennsylvanica Marsh.) is widely distributed in upland and riparian woodlands in the Great Plains region of North America. It is an important component of agroforestry and urban plantings in the Great Plains and Rocky Mountain regions. Observations by foresters suggest that green ash in some areas of these regions is in decline. Ash yellows (AshY) has sometimes been associated with severe growth reduction and dieback of ash in other areas of North America (13) and was recently discovered in the Great Plains and Rocky Mountain regions (20). AshY is perceived as a possible cause of the purported decline and thus as a threat to ash in these regions.

AshY, apparently caused by phytoplasmas of the AshY group (4), affects several ash species (14) and occurs widely in the United States and in southeastern Canada $(14,20)$. AshY was first found in the Great Plains in 1993 (19), and by 1996, it was known in parts of North Dakota, Nebraska, South Dakota, and Montana (20). Phytoplasmas in green ash at these sites were detected by electron microscopy, 4,6-dia-

Accepted for publication 23 November 1999.

Publication no. D-2000-0113-01R

(C) 2000 The American Phytopathological Society
midino-2-phenylindole-2HCl (DAPI) testing, and polymerase chain reaction (PCR) using universal phytoplasma-specific primers $(19,20)$. AshY phytoplasmas were identified by immunofluorescence (IF) tests using an AshY phytoplasma-specific monoclonal antibody (4) and restriction fragment length polymorphism (RFLP) analysis of PCR products (5). Most of the infected trees observed from 1993 to 1995 in these regions had witches'-brooms and severe crown dieback, giving the impression that AshY was causing substantial damage.

AshY was found as commonly in green ash natural stands as in white ash natural stands in four midwestern states (9) and was found in all sampled sites and $16 \%$ of the green ash trees surveyed in community forests in Iowa and Wisconsin (3). Green ash is more tolerant (less growth loss, less crown dieback) than white ash $(2,10,17)$. Sinclair et al. (15) and Gleason et al. (3) found that infected green ash grew at rates only 70 and $50 \%$, respectively, of noninfected trees. Green ash families from the Great Plains varied in tolerance of New York strains of AshY phytoplasmas (18). Thus, it appeared possible that AshY could damage green ash in the Great Plains and Rocky Mountain regions.

The goals of this study were to assess the health of established green ash and to determine the distribution, incidence, and effect of AshY phytoplasmas in the Great Plains and Rocky Mountain regions. A preliminary report has been published (21).

\section{MATERIALS AND METHODS}

Green ash trees were sampled at 106 sites in six states of the United States and three provinces of Canada (Fig. 1). Six to 15 sites in each state or province were selected without bias for green ash condition or presence of AshY phytoplasmas. A site was defined as a stand or part of a stand of trees containing green ash that was geographically distinct from other sites. All sampling was done in July to early September of 1996 and 1997. Natural stands $(\mathrm{N})$, rural plantings (R), and urban plantings (U) were sampled. Representation of each site type in the sample reflected availability or occurrence and ranged from equal (Manitoba, North Dakota, South Dakota, Nebraska) to heavily skewed toward urban plantings (percentage in $\mathrm{N}, \mathrm{R}$, and $\mathrm{U}$ site types 30 , 30, 40 (Saskatchewan); 0, 50, 50 (Alberta); 20, 27, 53 (Kansas); 13, 27, 60 (Colorado); and 12, 11, 78 (Wyoming), respectively). The overall representation was 25,30 , and $45 \% \mathrm{~N}, \mathrm{R}$, and U, respectively. All sampled trees were at least 20 years old.

Initially, 10 trees were systematically selected at each site by dividing the total number of green ash $(x)$ by 10 and then sampling every $(x / 10)$ th tree from a randomly selected starting point. The location (position within the sampled area), diameter at $1.4 \mathrm{~m}$ aboveground (to the nearest $0.1 \mathrm{~cm}$ ), estimated amount of dieback in the crown (crown class 1: $<10 \%$ of branches dead, 2: 10 to $25 \%$, and 3: $>25 \%$ ), and presence of putative AshY symptoms $(13,18)$ were recorded for each sampled tree. The recorded symptoms were witches'-brooms, deliquescent branching (lack of terminal dominance on branch ends), epicormic sprouts on the trunk, and basal shoots from near or below the ground line. An increment core representing the most recent 20 years of radial tree growth was taken from each tree, usually at $1.4 \mathrm{~m}$ height, to determine rate of growth. The width of the growth increment during the previous 1 to 5 years, 6 to 10 years, and 11 to 20 years was measured. Up to five additional trees were then selectively sampled 
at each site until at least five trees were represented from crown class 1 and from a combination of crown classes 2 and 3. This sample was taken to permit a site-by-site comparison of incidence of AshY phytoplasmas between relatively healthy trees and those with substantial crown dieback.

Roots were collected from every sampled tree for phytoplasma analysis. A live root segment $(0.5$ to $3 \mathrm{~mm}$ diameter and at least $5 \mathrm{~cm}$ long) was collected near the trunk from two sides of the tree. Attachment of sampled roots to the designated trees was confirmed. Root segments were wrapped in damp paper towels and placed in labeled plastic bags in an ice chest during the sampling period. If a witches'broom was present on a sampled tree, a shoot with leaves from the broom was collected and placed with the roots. Samples were delivered to North Dakota State University and refrigerated $\left(4^{\circ} \mathrm{C}\right)$ until sectioned. Several cross-sections of each root were made with a razor blade by hand while viewing through a dissecting microscope. Eight or more sections approximately 30 to $80 \mu \mathrm{m}$ thick from each of the two root samples were stored together in acetone in a labeled vial. Leaf petioles and rachises and succulent shoots were similarly sectioned and stored in separate vials.

AshY phytoplasmas were detected by IF microscopy of sections treated with an AshY phytoplasma-specific monoclonal antibody (4; source of antibody: T. A. Chen, Rutgers University, New Brunswick, $\mathrm{NJ})$ following methods described by Guo et al. (6). This antibody has been found to be active for only AshY phytoplasmas in tests involving many phytoplasma groups (4), and detection of AshY phytoplasmas using the antibody has been consistently confirmed by presence of phytoplasmas when checked using electron microscopy

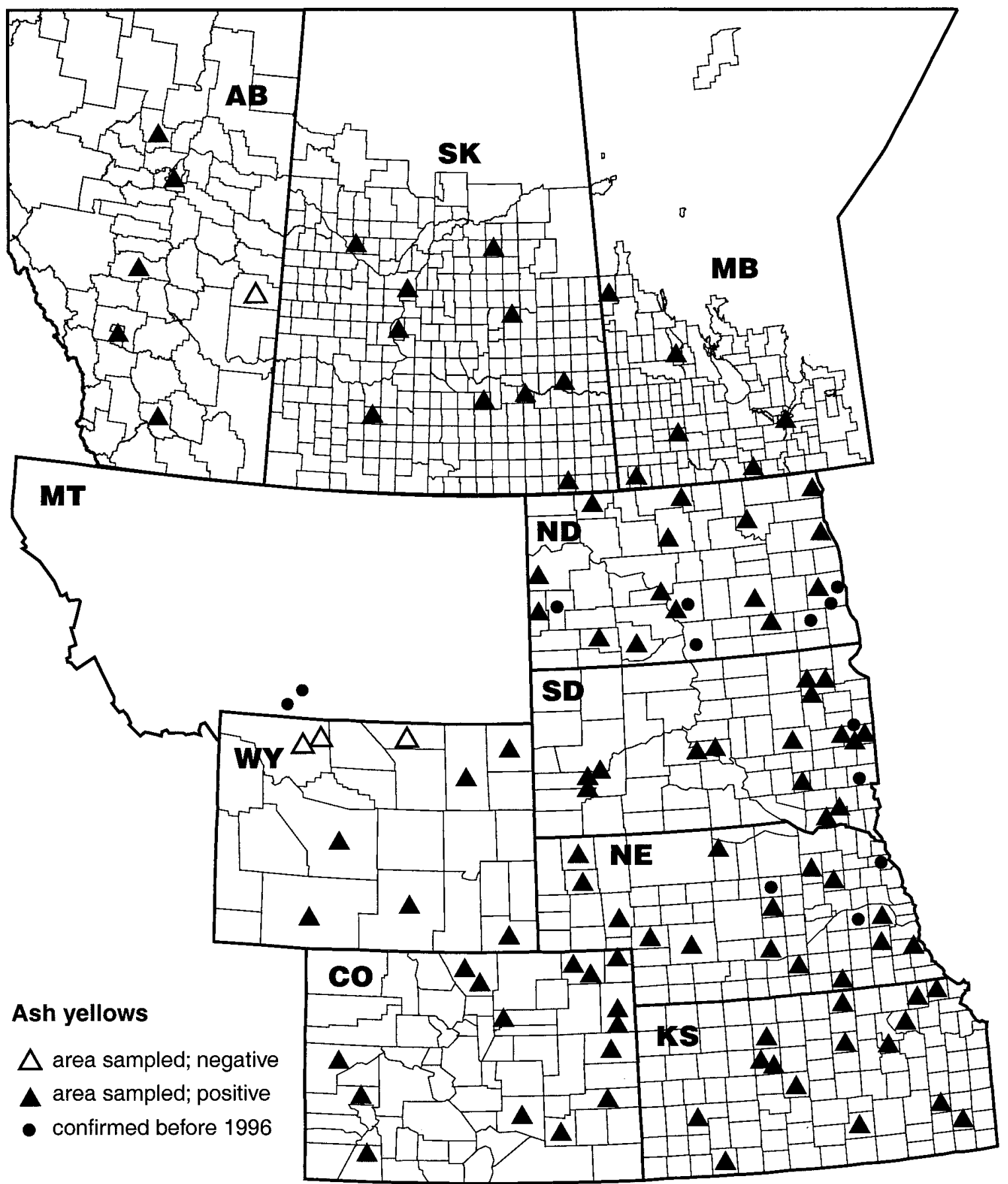

Fig. 1. Known distribution of ash yellows phytoplasmas in the Great Plains and Rocky Mountain regions of North America. 
and by typical bands when checked using AshY phytoplasma-specific primers in PCR (Y. Guo, unpublished data). For assays, about 10 root sections were taken so that some sections from each root segment were included. Samples rated positive or negative for IF are subsequently referred to as infected or not infected, respectively. To guard against false positive ratings caused by incomplete removal of the fluorescent stain (fluorescein isothiocyanate [FITC]) or accidental transfer of positive sections from the previous sample, a baseline threshold was set. A sample was scored positive only if at least three phloem cells with characteristic bright green IF were observed at $\times 100$ in each of at least three sections. If an IF-like reaction was observed, but it was below the threshold, the assay was repeated using the remaining or additional sections. If the total number of IF-positive cells and root sections in the additional sample plus those in the first sample reached the threshold, the sample was considered positive. Up to three assays (with additional sectioning being done when needed) were done for questionable samples. The brilliance of IF was recorded relative to the positive control; if the IF was at least as bright as the positive control, it was recorded as "strong" IF, and samples so rated were subjectively considered to have a relatively high phytoplasma titer. Strong IF was scored to allow consideration that a greater impact might occur when there is a higher phytoplasma titer.

Root sections from an infected green ash with witches'-brooms and from a noninfected green ash were included as positive and negative controls in each IF assay. The controls were verified with the monoclonal antibody and by DNA amplification with the universal phytoplasma-specific primers $\mathrm{R} 16 \mathrm{~F} 2$ and R16R2 (8). In addition to using the same positive and negative controls in 1996 and 1997, additional sections from roots collected and sectioned in 1996 from six trees rated positive for AshY phytoplasmas in 1996 were assayed again in
1997. The 1996 samples were all positive again in 1997.

Data were summarized overall and by sampling units (states and provinces, site types). The detection of AshY phytoplasmas was compared with site type, crown dieback class, growth ring width, tree diameter, and possible disease symptoms. Statistical analyses used were $t$ tests for quantitative measurements (growth ring width, tree diameter) and likelihood ratio chi-square tests for qualitative measurements (site type, crown class, symptoms). In addition, infections in trees without (crown class 1) and with (crown classes 2 and 3) substantial dieback within sites were assessed in paired comparison analysis. The selected critical probability level for each test was $P=0.10$. The states and provinces are listed in the tables primarily from north to south and secondarily from west to east to facilitate detection of geographic patterns.

\section{RESULTS}

Condition of green ash. More than half of the trees had $10 \%$ or more crown dieback (Table 1). The range among states and provinces of percentage of trees with $10 \%$ or more crown dieback was 33\% (Colorado) to $77 \%$ (Nebraska). There was no apparent geographic effect on overall crown condition. There was a site type effect on crown condition $(P<0.01$, Table 2 ). Within site types, $35 \%$ of the trees in rural plantings were in crown class 1 , compared with $59 \%$ in urban plantings. Among site types (Table 3), the highest percentage of trees in crown class 3 was in rural plantings (46\%), while the highest percentage of trees in crown class 1 was in urban plantings $(56 \%)$. Trees in crown class 1 had smaller trunk diameters than those in crown classes 2 and 3 (Table 2).

The average growth ring width was lower in the most recent 1 - to 5-year increment than in the 6- to 10 -year or 11 - to 20 -year increments, both overall and in six of the nine states and provinces (Table 1). This was also true $(P<0.01)$ for the age increments nested within crown classes and site types (Tables 2 and 3). The overall average growth ring widths of trees in crown classes 2 and 3 ( 2.5 and $2.4 \mathrm{~mm}$, respectively) were less than in crown class $1(3.5 \mathrm{~mm})$, and this relationship was also noted in each of the increment-core-age groups (Table 2). The overall average

Table 2. Relation of crown class of sampled green ash with site type, growth ring width, and tree diameter

\begin{tabular}{lcccc}
\hline & \multicolumn{3}{c}{ Crown class $^{\mathbf{v}}$} \\
\cline { 2 - 5 } Trait & $\mathbf{1}$ & $\mathbf{2}$ & $\mathbf{3}$ & $\boldsymbol{P}^{\mathbf{w}}$ \\
\hline Site type $^{\mathrm{x}}$ (\% trees) & & & $<0.01^{*}$ \\
$\quad$ Natural & 43 & 43 & 14 & $<0.01^{*}$ \\
Rural & 35 & 38 & 28 & $<0.01^{*}$ \\
Urban & 59 & 27 & 14 & \\
Growth ring widthy (mm) & & & 2.4 & $<0.01^{*}$ \\
Overall & 3.5 & 2.5 & $1.9 \mathrm{~b}$ & $<0.01^{*}$ \\
1- to 5-year increment & $3.1 \mathrm{a}$ & $2.2 \mathrm{~b}$ & $2.4 \mathrm{~b}$ & $<0.01^{*}$ \\
6- to 10-year increment & $3.9 \mathrm{a}$ & $2.6 \mathrm{~b}$ & $2.6 \mathrm{~b}$ & $<0.01^{*}$ \\
11- to 20-year increment & $3.5 \mathrm{a}$ & $2.6 \mathrm{~b}$ & $34.6 \mathrm{~b}$ & \\
Trunk diametery $(\mathrm{cm})$ & $31.5 \mathrm{a}$ & $34.4 \mathrm{~b}$ &
\end{tabular}

${ }^{v}$ Crown class 1: <10\% branch dieback; $2: 10$ to $25 \%$; 3 : $>25 \%$.

${ }^{\text {w }}$ Probabilities of a significant difference; $*=$ significant at $P \leq 0.10$.

${ }^{x}$ Compared in likelihood ratio chi-square tests.

y Compared in $t$ tests; values with different letters within rows differed significantly $(P \leq 0.05)$.

${ }^{\mathrm{z}}$ Summary data, statistical analyses not done.

Table 1. Crown class, diameter, and growth ring width of systematically sampled green ash, by location

\begin{tabular}{|c|c|c|c|c|c|c|c|c|c|}
\hline \multirow[b]{2}{*}{ Location $^{v}$} & \multicolumn{3}{|c|}{ Percent trees in each crown class ${ }^{w}$} & \multirow{2}{*}{$\begin{array}{l}\text { Crown class } \\
\text { index }^{x}\end{array}$} & \multirow{2}{*}{$\begin{array}{l}\mathrm{dbh}^{\mathrm{y}} \\
(\mathrm{cm})\end{array}$} & \multicolumn{4}{|c|}{ Growth ring width $^{\mathrm{z}}(\mathrm{mm})$} \\
\hline & 1 & 2 & 3 & & & $1-5 \mathrm{yr}$ & 6-10 yr & $11-20 \mathrm{yr}$ & $1-20 \mathrm{yr}$ \\
\hline Overall & 48 & 34 & 18 & 1.70 & 33.1 & 2.6 & 3.2 & 3.0 & 2.9 \\
\hline $\mathrm{AB}$ & 65 & 15 & 20 & 1.55 & 23.6 & 2.2 & 2.6 & 3.5 & 2.9 \\
\hline SK & 39 & 36 & 25 & 1.86 & 25.9 & 1.5 & 1.7 & 2.3 & 1.9 \\
\hline MB & 47 & 40 & 13 & 1.66 & 26.9 & 2.2 & 2.4 & 2.5 & 2.4 \\
\hline ND & 56 & 32 & 12 & 1.56 & 28.5 & 1.8 & 1.7 & 1.9 & 1.8 \\
\hline SD & 54 & 35 & 11 & 1.57 & 36.2 & 2.9 & 2.7 & 2.3 & 2.6 \\
\hline WY & 52 & 41 & 7 & 1.55 & 33.6 & 2.0 & 4.0 & 3.9 & 3.5 \\
\hline NE & 23 & 51 & 26 & 2.03 & 35.7 & 3.0 & 2.6 & 2.9 & 2.8 \\
\hline $\mathrm{CO}$ & 67 & 23 & 11 & 1.46 & 35.5 & 3.7 & 7.2 & 5.7 & 5.6 \\
\hline KS & 36 & 30 & 34 & 1.98 & 40.1 & 3.0 & 3.2 & 3.1 & 3.1 \\
\hline
\end{tabular}

$\mathrm{AB}=$ Alberta, $\mathrm{SK}=$ Saskatchewan, $\mathrm{MB}=$ Manitoba, ND = North Dakota, SD = South Dakota, WY = Wyoming, NE = Nebraska, CO = Colorado, and KS $=$ Kansas.

${ }^{\mathrm{w}}$ Crown class 1: <10\% branch dieback; 2 : 10 to $25 \%$; 3 : >25\%.

${ }^{\mathrm{x}}$ Weighted mean crown class based on sum of percentages in each crown class times crown class ratings.

y Mean diameter at breast height $(1.4 \mathrm{~m})$.

${ }^{\mathrm{z}}$ Mean annual growth ring width in each increment age group. 
growth ring width was larger in urban plantings $(3.7 \mathrm{~mm})$ than in rural plantings $(2.3 \mathrm{~mm})$ or natural stands $(2.2 \mathrm{~mm})$, as it was also in each of the increment-core-age groups $(P<0.01$, Table 3$)$.

Geographical trends were observed for growth rate, crown class, and tree size (Tables 1 and 4). Trees in the four southernmost states tended to have the greatest incremental growth rates. Within crown class 3, growth rates were highest in the western and southern parts of the sampled area, while growth rates were generally highest in the western part for crown class 2 and in the southern part for crown class 1 . Tree diameters were larger toward the south.

Incidence of AshY phytoplasmas. AshY phytoplasmas were identified at all 90 sites sampled in 1996 and at 12 of 16 sites sampled in 1997 (Fig. 1, Table 5). These phytoplasmas occurred in $50 \%$ of the 1,057 systematically sampled trees. The incidence of infection varied among states and provinces, ranging from $16 \%$ in Wyoming to $71 \%$ in South Dakota. Incidence within sites ranged from $0 \%$ at five sites in Alberta, North Dakota, and Wyoming to $100 \%$ at four sites in Nebraska, Colorado, and Kansas.

Overall incidence of AshY phytoplasmas differed among site types $(P<$ 0.01 , Table 6), with rural plantings having among the highest incidence both overall $(60 \%)$ and in seven of the nine states and provinces. Overall incidence of AshY phytoplasmas was higher in trees with poorer crown conditions $(P=0.06$, Table $6)$. The differences were greatest between crown classes 1 and 3 in natural stands (Table 7). However, incidence was also relatively high (47\%) in trees in the healthiest crown class, and no individual state or province had significant differences in incidence as related to crown condition. Within-site paired comparisons gave no indication that trees with substantial dieback were more or less likely to be infected than trees without substantial dieback $(P=0.78$, data not shown). $(79 \%)$ of the 29 trees with witches'brooms. Incidence of phytoplasmal infection was not higher in trees with deliquescent branches, epicormic sprouts, or basal sprouts than in trees without these symptoms (Table 8). Overall, deliquescent branches were present in $8 \%$ of the systematically sampled trees, epicormic sprouts on $39 \%$, and basal sprouts on $9 \%$.

No association was found between incidence of AshY phytoplasmas and radial growth rate of trees (Table 9). However, in Nebraska and South Dakota, average growth ring width in infected trees was significantly less $(P \leq 0.05)$ than in noninfected trees for the previous 1 to 5 years ( 2.6 versus $3.8 \mathrm{~mm}, 2.6$ versus $3.3 \mathrm{~mm}$, respectively) and 6 to 10 years (2.4 versus $3.1 \mathrm{~mm}, 2.4$ versus $3.3 \mathrm{~mm}$, respectively). Average trunk diameter did not vary between infected and noninfected trees overall; but when compared within site types, infected trees had larger average diameters than noninfected trees (Table 9).

When incidence of strong IF was considered in relation to host variables (data not shown), the results were similar to those using all IF data. The only notable change was that incidence of strong IF samples differed in each of the symptom trees with deliquescent branches $(P=$ 0.08 ), incidence higher than expected in trees with epicormic sprouts $(P=0.01)$, and incidence higher than expected in trees with basal sprouts $(P=0.02)$-whereas with all IF, the only difference was with deliquescent branches.

\section{DISCUSSION}

Because there is no prior baseline information on the condition of green ash in the sample area, determination of the current condition requires subjective judgment. In a population in excellent condition, dieback (an indicator of decline or prior damaging events) would be common only in over-mature individuals (those
AshY phytoplasmas were found in 23 types-incidence lower than expected in

undergoing decline as a late phase of the normal life cycle), and average growth would be sustained over time at a relatively fast rate.

The only crown condition data comparable to ours are from Iowa, Illinois, Missouri, and Wisconsin (3,9). Luley et al. (9) reported that $44 \%$ of the sampled green ash in natural stands had $11 \%$ or more crown dieback, while we found $57 \%$ with $10 \%$ or more crown dieback in natural stands. Gleason et al. (3) found that $65 \%$ of the green ash in urban plantings had $10 \%$ or more crown dieback (M. L. Gleason, Iowa State University, personal communication), while we found $41 \%$ with $10 \%$ or more crown dieback in urban plantings. Thus, green ash trees in our sample were in relatively poor condition in natural stands and in relatively good condition in urban plantings. We arbitrarily considered an incidence of about $25 \%$ of the trees with greater than $25 \%$ crown dieback or about $60 \%$ of the trees with $10 \%$ or more crown dieback to be associated with stands in poor condition. Based on the amount of crown dieback, the condition of the sampled trees is considered fair overall, good in Colorado, and poor in Kansas, Nebraska, and Saskatchewan.

Growth ring widths in our sampled population were lower than other published values from central North America. Naylor (11) reported that green ash growth ring width in rural plantings in eastern North Dakota was $2.3 \mathrm{~mm}$, the same as the overall average in rural plantings in our study. However, the width in our North Dakota rural plantings was only $1.6 \mathrm{~mm}$. The green ash in the windbreaks studied by Naylor were probably younger and growing more vigorously than those in our sample, possibly accounting for the greater radial growth rates. Johnson (7) reported that green ash in natural stands in the Missouri River floodplain in North Dakota had an average growth ring width of $2.1 \mathrm{~mm}$. Stroh (R. K. Stroh. 1996. Forest habitat

Table 4. Average growth ring width $(\mathrm{mm})$ of green ash trees with different crown classes

Table 3. Relation of sampled green ash site types with crown class, growth ring width, and tree diameter

\begin{tabular}{|c|c|c|c|c|}
\hline \multirow[b]{2}{*}{ Trait } & \multicolumn{3}{|c|}{ Site type } & \multirow[b]{2}{*}{$P^{\mathbf{v}}$} \\
\hline & Natural & Rural & Urban & \\
\hline \multicolumn{5}{|l|}{ Crown class ${ }^{\mathrm{w}, \mathrm{x}}(\%$ trees $)$} \\
\hline 1 & 22 & 22 & 56 & $<0.01 *$ \\
\hline 2 & 31 & 33 & 36 & $<0.01 *$ \\
\hline 3 & 19 & 46 & 35 & $<0.01 *$ \\
\hline \multicolumn{5}{|l|}{ Growth ring width ${ }^{y}(\mathrm{~mm})$} \\
\hline Overall $^{z}$ & 2.2 & 2.3 & 3.7 & \\
\hline 1- to 5 -year increment & $2.1 \mathrm{a}$ & $2.0 \mathrm{a}$ & $3.2 \mathrm{~b}$ & $<0.01 *$ \\
\hline 6- to 10 -year increment & $2.2 \mathrm{a}$ & $2.5 \mathrm{a}$ & $4.2 \mathrm{~b}$ & $<0.01^{*}$ \\
\hline 11 - to 20 -year increment & $2.3 \mathrm{a}$ & $2.4 \mathrm{a}$ & $3.8 \mathrm{~b}$ & $<0.01 *$ \\
\hline Trunk diameter ${ }^{\mathrm{y}}(\mathrm{cm})$ & $29.3 \mathrm{~b}$ & $25.1 \mathrm{a}$ & $40.4 \mathrm{c}$ & $<0.01 *$ \\
\hline
\end{tabular}

${ }^{v}$ Probabilities of a significant difference; $*=$ significant at $P \leq 0.10$.

${ }^{\mathrm{w}}$ Crown class 1: $<10 \%$ branch dieback; 2 : 10 to $25 \% ; 3$ : $>25 \%$.

${ }^{x}$ Compared in likelihood ratio chi-square tests.

y Compared in $t$ tests; values with different letters within rows differed significantly $(P \leq 0.05)$.

${ }^{\mathrm{z}}$ Summary data, statistical analyses not done.

\begin{tabular}{lccc}
\hline & \multicolumn{3}{c}{ Crown class $^{\mathbf{y}}$} \\
\cline { 2 - 4 } Location $^{\mathbf{z}}$ & $\mathbf{1}$ & $\mathbf{2}$ & $\mathbf{3}$ \\
\hline Overall & 3.5 & 2.5 & 2.4 \\
AB & 3.3 & 3.4 & 2.1 \\
SK & 2.3 & 1.9 & 1.6 \\
MB & 3.2 & 1.8 & 1.4 \\
ND & 2.0 & 1.6 & 1.7 \\
SD & 3.2 & 1.9 & 1.6 \\
WY & 3.9 & 3.2 & 2.6 \\
NE & 4.0 & 2.7 & 2.2 \\
CO & 5.7 & 5.2 & 5.6 \\
KS & 3.9 & 2.5 & 2.9 \\
\hline y Crown class 1: <10\% branch dieback; $2: 10$ to \\
25\%; 3: >25\%. \\
z AB = Alberta, SK = Saskatchewan, MB = \\
Manitoba, ND = North Dakota, SD = South \\
Dakota, WY = Wyoming, NE = Nebraska, CO \\
= Colorado, and KS = Kansas.
\end{tabular}


type classification for the Sheyenne $\mathrm{Na}$ tional Grasslands, North Dakota. Incomplete Ph.D. diss. North Dakota State University, Fargo) found that green ash in the Sheyenne River Valley in North Dakota had an average growth ring width of $2.9 \mathrm{~mm}$. In our study, the North Dakota natural stand average was $1.2 \mathrm{~mm}$, a Missouri River floodplain site average was $0.9 \mathrm{~mm}$, and a James River floodplain site (approximately $80 \mathrm{~km}$ from the Sheyenne River Valley study area) average was $1.0 \mathrm{~mm}$.

In urban plantings in Iowa and Wisconsin, Gleason et al. (3) found that green ash had a 22-year average growth ring width of $5.9 \mathrm{~mm}$, compared with our overall average in urban areas of $3.7 \mathrm{~mm}$. Gleason et al. (3) found that AshY phytoplasma-infected green ash growth ring width was 3.4 $\mathrm{mm}$, while it was $6.4 \mathrm{~mm}$ in noninfected trees. The respective growth ring widths in urban areas in our study were 3.8 and 3.7 $\mathrm{mm}$. These comparisons indicate that green ash in each site type in our sample were growing relatively slowly.

Thus, the overall condition of green ash in the Great Plains and Rocky Mountain regions was found to be only fair, providing documentation of earlier observations by foresters of decline in this species in these regions. The reasons for the high amount of dieback in the crown and the slow growth rate are not known. Multiple factors that could reduce green ash health have been identified $(1,12)$, but their impact on tree health has not been documented in these regions. Insect pests, including stem borers and leaf-feeding insects, and diseases, including stem decays and leaf diseases, are common in some areas. Herbicides are commonly applied to control weeds in the area of trees in each of the site types. Most sites in these regions are characterized by a relatively severe environment for broadleaf trees, including one or more of the following: extremes in high and low temperature, periodic flooding and drought, unfavorable soils for green ash, and damaging snow, freezing rain, and hail storms. However, although difficult to quantify, none of the above factors were recognized as influencing the amount of dieback or rate of growth of the sampled trees.

Trees in crown class 1 had smaller diameters and faster radial growth rates. This was likely due to those trees being younger and more vigorous. Younger, more vigorous trees would be expected to have less dieback.

This survey substantially expanded the known range of AshY phytoplasmas in

Table 5. Percentages of green ash trees in which ash yellows (AshY) phytoplasmas were detected at each sampled site in each state or province (systematically sampled trees only)

\begin{tabular}{lccc}
\hline Location & Number of sites & Trees sampled & $\begin{array}{c}\text { Trees with AshY phytoplasmas } \\
\text { (\%, avg. and range) }\end{array}$ \\
\hline AB & 6 & 60 & $18(0-50)$ \\
SK & 10 & 100 & $48(20-70)$ \\
MB & 6 & 60 & $48(20-80)$ \\
ND & 15 & 150 & $28\left(0^{z}-50\right)$ \\
SD & 15 & 150 & $71(20-90)$ \\
WY & 9 & 87 & $16(0-33)$ \\
NE & 15 & 150 & $66(20-100)$ \\
CO & 15 & 150 & $55(10-100)$ \\
KS & 15 & 150 & $67(10-100)$ \\
Overall & 106 & 1,057 & $50(0-100)$ \\
\hline
\end{tabular}

y All sites in Manitoba (MB), North Dakota (ND), South Dakota (SD), Nebraska (NE), Colorado (CO), Kansas (KS), and nine sites in Saskatchewan (SK) sampled in 1996; all sites in Alberta (AB), Wyoming (WY), and one site in SK sampled in 1997.

${ }^{\mathrm{z}}$ AshY phytoplasmas detected in nonsystematic sample.
North America. These phytoplasmas occur at most sites with 20-year-old and older green ash in the sampled states and provinces. AshY phytoplasmas had not been previously found in Alberta, Saskatchewan, Manitoba, Wyoming, Colorado, or Kansas. The presence of AshY phytoplasmas at most sites over this relatively large area supports a hypothesis that they are endemic in these regions. Alternatively, all of more than 1,000 witches'-brooms that have been observed in these regions, including those found in this study and in others (J. A. Walla, unpublished data), appeared to have been initiated in 1991 or later, based on size and patterns of growth, and no dead trees with witches'-brooms were noted. These observations support an alternative hypothesis that the phytoplasmas have recently moved into these regions. These conflicting observations prevent conclusions concerning the length of time that AshY phytoplasmas have occurred in these regions.

The incidence of AshY phytoplasma-infected trees in the sampled area is likely higher than the $50 \%$ reported here. The use of IF assays, a moderately sensitive method (6), in a conservative manner probably underestimated the percentage of samples infected. Also, use of small-diameter root sections (e.g., <1 mm) may have resulted in an underestimate of incidence. We noticed that in samples composed of root sections of two substantially different diameters, the larger diameter sections most often were the ones with IF. Of 14 samples with both large and small diameter root sections, IF was present in only the larger diameter sections of 11 samples and in only the smaller diameter sections of one sample. Root diameter was usually not recorded, so an assessment of how this may have affected our results is not possible. The size effect was noticed after samples from one state (North Dakota) were done, and larger roots were sectioned when available thereafter.

Witches'-brooms are considered to be diagnostic for AshY (14), but we found

Table 6. Incidence of ash yellows phytoplasmas (\% infected trees) in green ash by site type and crown class

\begin{tabular}{|c|c|c|c|c|c|c|c|}
\hline \multirow[b]{2}{*}{ Location ${ }^{y}$} & \multicolumn{4}{|c|}{ Site type $^{w}$} & \multicolumn{3}{|c|}{ Crown class ${ }^{x}$} \\
\hline & $\mathbf{N}$ & $\mathbf{R}$ & $\mathbf{U}$ & $P^{\mathbf{z}}$ & 1 & $2 \& 3$ & $P^{z}$ \\
\hline Overall & 45 & 60 & 47 & $<0.01 *$ & 47 & 53 & $0.06^{*}$ \\
\hline $\mathrm{AB}$ & $\ldots$ & 13 & 23 & 0.31 & 23 & 10 & 0.18 \\
\hline SK & 50 & 60 & 38 & 0.17 & 56 & 43 & 0.18 \\
\hline MB & 35 & 55 & 55 & 0.34 & 50 & 47 & 0.81 \\
\hline ND & 18 & 38 & 28 & $0.08^{*}$ & 31 & 24 & 0.36 \\
\hline SD & 58 & 84 & 72 & $0.12 *$ & 67 & 77 & 0.17 \\
\hline WY & 20 & 0 & 18 & 0.15 & 16 & 17 & 0.85 \\
\hline $\mathrm{NE}$ & 68 & 84 & 46 & $<0.01 *$ & 62 & 67 & 0.56 \\
\hline $\mathrm{CO}$ & 35 & 70 & 53 & $0.03^{*}$ & 54 & 58 & 0.64 \\
\hline KS & 47 & 73 & 71 & $0.04^{*}$ & 59 & 71 & 0.15 \\
\hline
\end{tabular}

${ }^{\text {w }} \operatorname{Natural}(\mathrm{N})$, Rural (R), or Urban (U).

${ }^{x}$ Crown class 1: $<10 \%$ crown dieback; $2 \& 3: 10 \%$ or greater crown dieback.

y $\mathrm{AB}=$ Alberta, $\mathrm{SK}=$ Saskatchewan, $\mathrm{MB}=$ Manitoba, ND = North Dakota, $\mathrm{SD}=$ South Dakota, $\mathrm{WY}=$ Wyoming, $\mathrm{NE}=\mathrm{Nebraska}, \mathrm{CO}=\mathrm{Colorado}$, and KS = Kansas.

${ }^{\mathrm{z}}$ Probabilities of a significant difference, based on likelihood ratio chi-square analyses; $*$ = significant at $P \leq 0.10$. 
that only $79 \%$ of the 29 sampled were positive for AshY phytoplasmas. Similarly, Gleason et al. (3) found that only 54\% of the trees with witches'-brooms in Iowa and Wisconsin were positive for AshY phytoplasmas. In our sample, the likely explanation for negative assays of witches'brooms is that the assays did not detect phytoplasmas in some infected plants and that some growths were mistakenly classified as witches'-brooms.

Incidence of phytoplasmal infection was much lower than average in Alberta (18\%) and Wyoming (16\%). In Canada, the natural range of green ash is approximately along the Alberta-Saskatchewan border, presenting the possibility that the absence of a natural inoculum reservoir or scarcity of vectors results in reduced phytoplasma incidence. The low detected incidence in Wyoming might be similarly explained because it is mostly outside the natural range of green ash. However, the detected incidence was relatively high $(55 \%)$ in Colorado, but this state is also mostly outside the natural range of green ash.

The incidence of AshY phytoplasmas in green ash in our study is similar to that reported in some white ash stands in New York (10), but it is much higher than previous reports of incidence in green ash. Luley et al. (9) detected AshY phytoplasmas in $49 \%$ of 41 green ash plots in Illinois, Iowa, Missouri, and Wisconsin, much lower than the $96 \%$ reported here. Gleason et al. (3) detected AshY phytoplasmas at all sampled sites and in $16 \%$ of more than 300 arbitrarily selected green ash in nine cities in Iowa and Wisconsin, also much lower than the $50 \%$ reported here. The primary differences between our study and those are location and assay method.

The larger trunk diameters of infected compared with noninfected trees within site types may be associated with tree age. The smaller diameter, putatively younger trees may have been exposed to infection for fewer years. Sampling of various age classes of trees would be needed to confirm this relationship.

The differences in incidence of AshY phytoplasmas among site types were statistically significant, but incidences were each relatively high (45 to $60 \%$ ). These levels would be a major concern in each site type if the infected trees are threatened, but we still do not know if AshY poses a substantial threat in these regions. Although there was an association of the presence of AshY phytoplasmas with the amount of dieback in the crown, the incidence in each crown class was relatively high (47 to 57\%), and we do not know if AshY phytoplasmas caused the poorer crown condition. An association of presence of AshY phytoplasmas with radial growth rate was not found. These findings (high phytoplasma incidence, apparently low impact) are similar to those regarding velvet ash ( $F$. velutina Torr.) in Zion National Park in Utah $(15,16)$.

Sinclair et al. (16) noted that different plants may have different titers of AshY phytoplasmas. Lower titers were generally found in velvet ash, in which there was a relatively low impact from AshY phytoplasmal infection compared with white ash. Strong IF should be an indicator of a higher titer of AshY phytoplasmas, so our comparisons using that measurement might have allowed detection of damage in more serious cases or advanced stages of AshY. Results using strong IF gave generally similar results as using all IF, so a higher phytoplasma titer was apparently not associated with a stronger effect on infected green ash

Several explanations are possible for failure to identify a clear effect of AshY phytoplasmas in the Great Plains and Rocky Mountain regions. One is that an impact may not be present. Alternative explanations include (i) the presence of several other factors that cause dieback and slow growth in green ash (e.g., drought, flooding, insect borers, herbicide damage, other pathogens), (ii) the presence of at least some resistant host or avirulent pathogen germ plasm in the sampled regions (14), (iii) recent expansion of AshY phytoplasmas into these regions, precluding adequate time to cause an impact, and (iv) detection of AshY phytoplasmas at a concentration substantially above or below that which results in growth reduction or crown dieback. If even one of these possible complicating factors was present, detection of an impact by AshY phytoplasmas would have been difficult, and it is likely that more than one of the factors was present. Direct assessment in controlled studies of the impact that AshY phytoplasmas may have in these regions is needed.

\section{ACKNOWLEDGMENTS}

The study was facilitated by partial funding from the USDA Forest Service, Forest Health Management, Lakewood, CO, and the PFRA

Table 7. Percent green ash with ash yellows phytoplasmas in each crown dieback class

\begin{tabular}{lcccc}
\hline & \multicolumn{3}{c}{ Crown class $^{\mathbf{y}}$} & \\
\cline { 2 - 4 } Site type & $\mathbf{1}$ & $\mathbf{2}$ & $\mathbf{3}$ & $\boldsymbol{P}^{\mathbf{z}}$ \\
\hline Overall & 47 & 51 & 57 & $0.06^{*}$ \\
Natural & 41 & 42 & 67 & $0.02^{*}$ \\
Rural & 62 & 63 & 55 & 0.40 \\
Urban & 44 & 47 & 56 & 0.23 \\
\hline
\end{tabular}

y Crown class 1: $<10 \%$ branch dieback; 2 : 10 to $25 \%$; 3 : $>25 \%$.

${ }^{\mathrm{z}}$ Probabilities of a significant difference, based on likelihood ratio chi-square analyses; $*=$ significant at $P \leq 0.10$.

Table 8. Percent green ash with ash yellows phytoplasmas in each symptom type

\begin{tabular}{lccc}
\hline & \multicolumn{2}{c}{ Symptom types } & \\
\cline { 2 - 3 } & With symptoms & Without symptoms & $\boldsymbol{P}^{\mathbf{y}}$ \\
\hline Deliquescent branches & 38 & 51 & $0.02^{*}$ \\
$\quad$ Site type $^{\mathrm{z}}$ & & & \\
$\quad$ Natural & 29 & 47 & $0.05^{*}$ \\
Rural & 52 & 61 & 0.38 \\
$\quad$ Urban & 33 & 47 & 0.17 \\
Epicormic sprouts & 53 & 49 & 0.22 \\
Basal sprouts & 57 & 50 & 0.17 \\
\hline
\end{tabular}

${ }^{\mathrm{y}}$ Probabilities of a significant difference, based on likelihood ratio chi-square analyses; $*$ = significant at $P \leq 0.10$.

${ }^{\mathrm{z}}$ Data for individual site types are presented only for variables in which infection frequency varied significantly within site type.

Table 9. Radial growth rate and tree diameter of green ash infected by ash yellows phytoplasmas versus apparently noninfected green ash

\begin{tabular}{lccc}
\hline & Infected & Not infected & $\boldsymbol{P}^{\mathbf{y}}$ \\
\hline Growth ring width (mm) & & & \\
1- to 5-year increment & 2.6 & 2.6 & 0.71 \\
6- to 10-year increment & 3.2 & 3.2 & 0.68 \\
11- to 20-year increment & 2.9 & 3.0 & 0.49 \\
Trunk diameter (cm) & & 32.4 & 0.17 \\
$\quad \begin{array}{l}\text { Overall } \\
\text { Site type }\end{array}$ & 33.7 & & \\
$\quad$ Natural & 30.8 & 28.1 & $0.08^{*}$ \\
$\quad$ Rural & 26.0 & 23.7 & $0.05^{*}$ \\
$\quad$ Urban & 41.8 & 39.1 & $0.07^{*}$ \\
\hline
\end{tabular}

${ }^{\text {y }}$ Probabilities of a significant difference, based on $t$ test analyses; $*$ significant at $P \leq 0.10$.

${ }^{\mathrm{z}}$ Data for individual site types are presented only for variables in which infection frequency varied significantly with site type. 
Shelterbelt Centre, Agriculture and Agri-Food Canada. Appreciation is expressed to: T. A. Chen, Rutgers University, for permission to use the ash yellows phytoplasma-specific monoclonal antibody; W. A. Sinclair, Cornell University, for supplying an ash yellows phytoplasma strain (AshY5) in periwinkle for use as a positive control; J. Ramsay, L. Stepanek, and J. Jennings for help in sampling; J. Ramsay and D. Galitz for help in sample assays; M. A. Draper and C. Ruby, NDSU Plant Pest Diagnostic Laboratory, for use of the fluorescence microscope; and Curt Doetkott, NDSU Information Technology Services, for data analyses.

\section{LITERATURE CITED}

1. Dix, M. E., Pasek, J. E., Harrell, M. O., and Baxendale, F. P., technical coordinators. 1987. Common insect pests of trees in the Great Plains. Nebraska Cooperative Extension Service EC-86-158. University of Nebraska, Lincoln.

2. Ferris, M. A., Castello, J. D., and Sinclair, W. A. 1989. Effects of virus and mycoplasmalike organism infection on green and white ash. Phytopathology 79:579-583.

3. Gleason, M. L., Parker, S. K., Engle, T. E., Flynn, P. H., Griffiths, H. M., Vitosh, M. A., and Iles, J. K. 1997. Ash yellows occurrence and association with slow growth of green ash in Iowa and Wisconsin cities. J. Arboric. 23:77-82.

4. Griffiths, H. M., Sinclair, W. A., Davis, R. E., Lee, I.-M., Dally, E. L., Guo, Y.-H., Chen, T. A., and Hibben, C. R. 1994. Characterization of mycoplasmalike organisms from Fraxinus, Syringa, and associated plants from geographically diverse sites. Phytopathology
84:119-126.

5. Griffiths, H. M., Sinclair, W. A., Smart, C. D., and Davis, R. E. 1999. The phytoplasma associated with ash yellows and lilac witches'broom: 'Candidatus Phytoplasma fraxini'. Int. J. Syst. Bacteriol. 49:1605-1614.

6. Guo, Y. H., Cheng, Z.-M., Walla, J. A., and Zhang, Z. 1998. Large-scale screening for Xdisease phytoplasma infection in chokecherry. HortScience 33:293-295.

7. Johnson, W. C. 1971. The forest overstory vegetation on the Missouri River floodplain in North Dakota. Ph.D. diss. North Dakota State University, Fargo.

8. Lee, I.-M., Hammond, R. W., Davis, R. E., and Gundersen, D. E. 1993. Universal amplification and analysis of pathogen $16 \mathrm{~S}$ rDNA for classification and identification of mycoplasmalike organisms. Phytopathology 83:834-842.

9. Luley, C. J., Mielke, M. E., Castello, J. D., Cummings Carlson, J., Appleby, J., and Hatcher, R. 1992. Ash crown condition and the incidence of ash yellows and other insects and diseases in Illinois, Iowa, Missouri, and Wisconsin. Plant Dis. 76:1209-1212.

10. Matteoni, J. A., and Sinclair, W. A. 1985. Role of the mycoplasmal disease, ash yellows, in decline of white ash in New York State. Phytopathology 75:355-360.

11. Naylor, J. N. 1969. Understory vegetation in shelterbelts of eastern North Dakota. Ph.D. diss. North Dakota State University, Fargo.

12. Riffle, J. W., and Peterson, G. W., eds. 1986. Diseases of trees in the Great Plains. USDA Forest Service, Gen. Tech. Rep. RM-129. Ft. Collins, $\mathrm{CO}$.
13. Sinclair, W. A., and Griffiths, H. M. 1994. Ash yellows and its relationship to dieback and decline of ash. Annu. Rev. Phytopathol 32:49-60

14. Sinclair, W. A., Griffiths, H. M., and Davis, R. E. 1996. Ash yellows and lilac witches'broom: Phytoplasmal diseases of concern in forestry and horticulture. Plant Dis. 80:468 475 .

15. Sinclair, W. A., Griffiths, H. M., and Treshow, M. 1993. Impact of ash yellows mycoplasmalike organisms on radial growth of naturally infected green, white, and velvet ash Can. J. For. Res. 23:2467-2472.

16. Sinclair, W. A., Griffiths, H. M., and Treshow, M. 1994. Ash yellows in velvet ash in Zion National Park, Utah: High incidence but low impact. Plant Dis. 78:486-490.

17. Sinclair, W. A., Marshall, P. T., and Kemperman, J. 1987. Mycoplasmal infection found in four ash species in midwestern states. Plant Dis. 71:761.

18. Sinclair, W. A., Whitlow, T. H., and Griffiths, H. M. 1997. Heritable tolerance of ash yellows phytoplasmas in green ash. Can. J. For. Res. 27:1928-1935.

19. Walla, J. A., Ash, C. L., and Draper, M. A 1994. Ash yellows in green ash in North Dakota. Plant Dis. 78:432.

20. Walla, J. A., and Guo, Y. H. 1996. Ash yellows in the northern Great Plains region. Plant Dis. 80:343-344

21. Walla, J. A., Jacobi, W. R., Tisserat, N. A., Harrell, M. O., Ball, J. J., Neill, G. B., and Reynard, D. A. 1997. Studies of ash yellows in the Great Plains region of North America. (Abstr.) Eur. J. For. Pathol. 28:83. 